\title{
Characteristics of Student's Creative Thinking in Solving Inquiry Problems
}

\author{
Chandra Kirana ${ }^{1,{ }^{*}}$ Budiyono $^{2}$ Diari Indriati ${ }^{3}$ \\ ${ }^{I}$ Magister of Mathematics Education, Faculty of Teacher Training and Education, Universitas Sebelas Maret, \\ Surakarta, Indonesia \\ ${ }^{2}$ Faculty of Teacher Training and Education, Universitas Sebelas Maret, Surakarta, Indonesia \\ ${ }^{3}$ Faculty of Mathematics and Natural Sciences, Universitas Sebelas Maret, Surakarta, Indonesia \\ *Corresponding author. Email: chandrakirana@student.uns.ac.id
}

\begin{abstract}
Creative thinking is an authentic and reflective way of thinking and produces a complex product. This study aimed to describe the characteristics of students' creative thinking in solving inquiry problems. This research method used descriptive qualitative. Data collection techniques in this study were creative thinking tests and interviews. The instruments used in this study were creative thinking test instruments and interview guidelines. The triangulation used was method triangulation. The subjects in this study were 20 grade VIII students of SMP Negeri 1 Nganjuk. The sampling technique used is purposive sampling. The data were analyzed through the stages of data reduction, data display, and drawing conclusions. The results showed there are four categories of creative thinking in solving inquiry problems. Students with less creative category can provide more than one alternative answer. Students with quite creative category can solve problems with more than one method. Students with creative category can provide more than one alternative answer and can give different answers from other students. Students with very creative category can provide more than one alternative answer with different methods and can give different answers from other students. Further research can develop an infused learning model to defragment students' creative level in solving inquiry problems.
\end{abstract}

Keywords: Characteristics, Creative thinking, Inquiry.

\section{INTRODUCTION}

The development of knowledge, information, and communication technology in the last century has shifted from manufacturing services to services that emphasize information and knowledge. Students are no longer focused on doing machine-assisted manual work, but they are more focused on communicating, solving complex problems, adapting, and innovating [1]. In the 21 st century, students are required to have essential skills. These skills are still relevant to the four pillars of life, namely learning to know, learning to do (working), learning to be (success), and learning to live together [2]. One of the essential skills to be developed in education is creative thinking skills [3]. Guilford identified two kinds of skills related to creativity, namely convergent and divergent thinking skills. Convergent thinking is based on finding a single solution to a given problem, while divergent thinking is focused on producing multiple solutions to a given problem from different points of view [4]. Creative thinking is an authentic and reflective way of thinking and produces a complex product. Included in creative thinking is synthesizing ideas, generating new ideas, and determining the effectiveness of existing ideas. Creative thinking skills are an essential aspect for students to solve a problem and find ideas to solve the problem [5].

There are three components of creativity, namely Fluency, Flexibility, and Originality. Fluency refers to the number of ideas that can be generated in response to a command. Then, flexibility refers to the number of approaches or methods, or strategies used to produce a response to a command. Lastly, Originality refers to the originality of ideas generated in response to a command [6]. The indicators for creative thinking are shown in Table 1 below. 
Table 1. Creative thinking indicators

\begin{tabular}{|l|l|}
\hline Aspects & Indicators \\
\hline Fluency & $\begin{array}{l}\text { Generate many ideas or alternative } \\
\text { answers in solving problems. }\end{array}$ \\
\hline Flexibility & $\begin{array}{l}\text { Generate ideas or alternative answers } \\
\text { by using several different } \\
\text { ways/methods based on their thinking. }\end{array}$ \\
\hline Originality & $\begin{array}{l}\text { Generate ideas or alternative answers } \\
\text { to solve problems or create new } \\
\text { combinations of parts or elements that } \\
\text { students are not accustomed to at their } \\
\text { level of knowledge. }\end{array}$ \\
\hline
\end{tabular}

The criteria are based on creative thinking products that pay attention to aspects of fluency, flexibility, and originality to focus on the creative thinking level of students. The level of creative thinking ability in mathematics formulated by Siswono [7] is shown in Table 2 below.

Table 2. Creative thinking ability level

\begin{tabular}{|l|l|}
\hline Levels & Characteristics \\
\hline $\begin{array}{l}\text { Level } 4 \\
\text { Very Creative) }\end{array}$ & $\begin{array}{l}\text { Students can show fluency, } \\
\text { flexibility, and originality, or } \\
\text { originality and flexibility in solving } \\
\text { problems. }\end{array}$ \\
\hline $\begin{array}{l}\text { (Creative) } 3 \\
\text { Level 2 }\end{array}$ & $\begin{array}{l}\text { Students can show fluency and } \\
\text { originality or fluency and flexibility } \\
\text { in solving problems. }\end{array}$ \\
\hline $\begin{array}{l}\text { Level 1 } \\
\text { (Less Creative) }\end{array}$ & $\begin{array}{l}\text { Students can show originality or } \\
\text { flexibility in solving problems. }\end{array}$ \\
\hline $\begin{array}{l}\text { Level 0 } 0 \\
\text { (Uncreative) }\end{array}$ & $\begin{array}{l}\text { Students can show fluency in } \\
\text { three aspects of creative thinking } \\
\text { indicators. }\end{array}$ \\
\hline
\end{tabular}

The development of creativity is currently considered very important in line with 21 st-century skills [8]. Empowerment of creativity can be done by providing inquiry-based learning that includes problem-solving, problem-posing, and activities that help students increase student capacity concerning the components of creativity [6]. Inquiry-based learning invites students to solve ill-structured but significant problems. Through ill-structured problems, students can construct, analyze, and criticize mathematical arguments. In class, students present and discuss their solutions on the board or in small groups while educators guide and monitor the discussion process [9].

The research that several previous researchers have done showed the contribution of inquiry-based argumentation [10]. In addition, inquiry learning can be used to form mathematical connections [11]. Through some literature that has been reviewed, some gaps need to be investigated regarding the characteristics of students' creative thinking in solving inquiry problems.

This study aimed to describe the characteristics of students' creative thinking in solving inquiry problems. The characteristics of students' creative thinking in solving inquiry problems need to be known to detect students' creative thinking levels so that students with less creative thinking levels can be given a stimulus that can improve their creative thinking. If there is no research that explores the characteristics of students' creative thinking in solving inquiry problems, the result is that students' creative thinking levels cannot be known. Thus, students' creative thinking levels cannot increase because there is no effort to improve their creative thinking.

\section{METHODOLOGY}

\subsection{Research Design}

This research used a qualitative descriptive study. Qualitative research produces descriptive data in the form of written or spoken words from people and observable behavior [12]. The data presented describe the characteristics of students' creative thinking in solving inquiry problems.

\subsection{Participants}

The subjects in this study were 20 students of SMP Negeri 1 Nganjuk. The selection of research subjects was based on several characteristics. They were student of grade VIII who had taken quadrilateral and triangle subjects and had good communication skills. The sampling technique used was purposive sampling. Purposive sampling is the selection of data sources by using certain considerations held by the researcher [13]. In this study, purposive sampling was done by selecting students who could communicate the data of creative thinking during interviews between participants dan researcher. The distribution of participants that could communicate the data during interviews presented in the following Table 3. 
Table 3. Distribution of communicative participants

\begin{tabular}{|c|c|c|}
\hline Category & $\begin{array}{c}\text { Number of } \\
\text { students in each } \\
\text { category }\end{array}$ & $\begin{array}{c}\text { Number of } \\
\text { communicative } \\
\text { students }\end{array}$ \\
\hline Level 4 & 1 & 1 \\
\hline Level 3 & 3 & 1 \\
\hline Level 2 & 2 & 2 \\
\hline Level 1 & 14 & 5 \\
\hline
\end{tabular}

However, in this article, only four students are reported from each category of creative thinking. Each of these students shows representative data as research data because the data from each student represents each category. In addition, these students can communicate creative thinking data.

\subsection{Research Instruments}

The instruments used in this study were creative thinking test instruments and interview guidelines. The test instrument used was three essay test questions with the topic of quadrilateral and triangle which contained indicators of creative thinking in solving inquiry problems. The instruments used in this study were validated by two validators, which were experts in mathematics and education. The validator stated that the instrument used represented all aspects of measuring creative thinking with quadrilaterals and triangles.

\subsection{Data Collection Technique}

Data collection techniques in this study were tests and interviews. Subjects were given a creative thinking test. The test was used to determine the category of student's creative thinking in solving inquiry problems. Figure 1 showed the creative thinking test instrument that was tested on the subject.

After giving the creative thinking test, students were interviewed as confirmation of the answers given when working on the creative thinking test. The validity of the data is carried out by implementing the triangulation method, that is the researcher compares the data obtained from the results of tests and interviews.

\subsection{Data Analysis}

The stages of data analysis in this study were data reduction, data presentation, and conclusion drawing [13]. In the data reduction stage, the selection of essential data needed to achieve the research objectives was carried out. Then, the findings were reduced to describe creative thinking data based on several categories. Furthermore, the researchers drew conclusions from the findings obtained to answer the study's objectives.

"One day, Soni wanted to make a kite. Soni measures and cuts the paper to be used. So, the paper is shaped like a kite with diagonals of $10 \mathrm{~cm}$ and $16 \mathrm{~cm}$. If Soni wants to make a triangle or quadrilateral whose area is the same as his kite, draw their shapes and sizes!"

"Mr. Ihsan has a pond with a shape like getting up below.

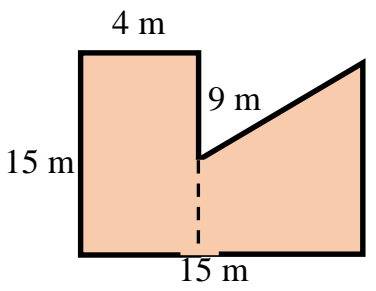

The pond will be filled with catfish. Before filling it with catfish, Mr. Ihsan wanted to know the area of the pond. Calculate the area of Pak Ihsan's pond!"

"Lusi has a square folded paper with a side length of $16 \mathrm{~cm}$, as shown below.

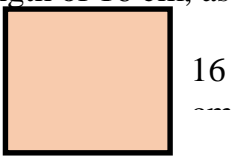

a. Determine the area of the folded paper!

b. Are there other planes that have the same area as the folded paper above? If there is, draw the plane and its size!"

Figure 1 Quadrilateral and triangle inquiry problems 


\section{FINDINGS}

Based on the results of the tests given to students, the researchers described data from one subject based on categories that matched creative thinking. There are four categories of creative thinking in solving inquiry problems. The data exposure is presented as follows.

\subsection{Category 1: Less Creative}

Figure 2 is the answer sheet for the RAA subject in the less creative category. In Figure 10, in working on problem number 1, RAA can draw another plane whose area is the same as the kite area. The planes made by RAA are triangles and rectangles and their sizes. Therefore, the RAA subjects met the fluency indicator. In answer to question number 2, RAA can determine the area of the composite plane by dividing the composite plane into two different planes, namely rectangles and trapezoids. However, RAA can only determine the area of the building in one way. Therefore, RA does not meet the flexibility indicator. In working on problem number 3, RAA can determine another plane whose area is the same as a square. However, the only plane that RAA can make are kites with a length of $32 \mathrm{~cm}$ on each diagonal and a width of $16 \mathrm{~cm}$. Therefore, AWS does not meet the originality indicator. This is complemented by excerpts from the interviews, as follows:

$\mathrm{R}$ : "In question number 1, how do you determine a plane whose area is the same as the kite known in the problem?"

RAA : "I first looked for the area of the kite, and then I made a triangle. From the formula for the area of a triangle, which is $1 / 2$ (at), I tried to enter the length of the base and the height until I found the area of $80 \mathrm{~cm}^{2}$. The rectangle is the same, and I tried the length and width until I found the same area."

R : "Good. Furthermore, in question number 2, what was asked in the question?"

RAA : "Determining the area of the plane."

$\mathrm{R} \quad$ : "How do you determine the area of the plane?"

RAA : "I divided the composite plane into two planes, namely a rectangle and a trapezoid. Then I find the area of each plane, and then I add up the area."

$\mathrm{R} \quad$ : : "Is there another way to divide the plane?"
RAA : "No, ma'am."

$\mathrm{R} \quad:$ "What if the composite plane is divided into three, namely two rectangles and a triangle?"

RAA : "Oh yes, ma'am. Yesterday I did not think of it that way."

$\mathrm{R} \quad$ : "Good. Then how do you work on question number 3 ?"

RAA : "Same as number 1, ma'am. I find the area of the square then tries to get another plane. Then, I can build a kite whose diagonals are $32 \mathrm{~cm}$ and $16 \mathrm{~cm} . "$

$\mathrm{R} \quad$ : "Is there any other planes besides a kite that has the same area as a square?"

RAA : "I was thinking about kites, ma'am."

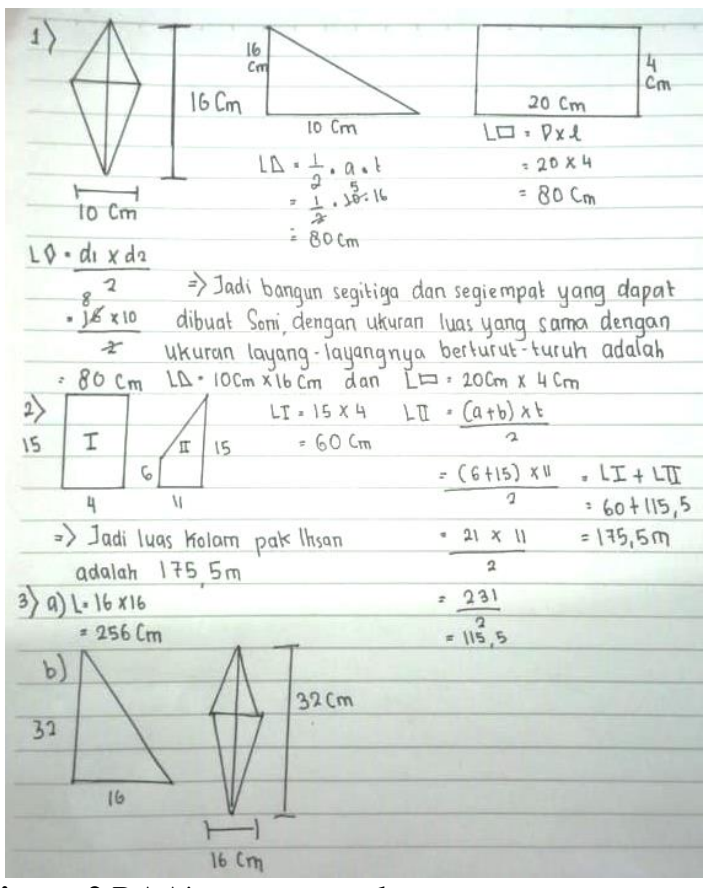

Figure 2 RAA's answer results

\subsection{Category 2: Quite Creative}

Figure 3, Figure 4, and Figure 5 are AWS subject answer sheets with quite creative categories. In Figure 3 , in working on problem number 1 , AWS can draw another plane with area equal to the kite area. However, the length and width measurements written on the image are not the same as those written when determining the area of the rectangle. Based on the interview results, information was obtained that the length and width measurements referred to by AWS are $16 \mathrm{~cm}$ and $5 \mathrm{~cm}$, respectively. When working on this problem, AWS can only create one plane, which is a rectangle. Therefore, RA does not meet the indicator of fluency. 


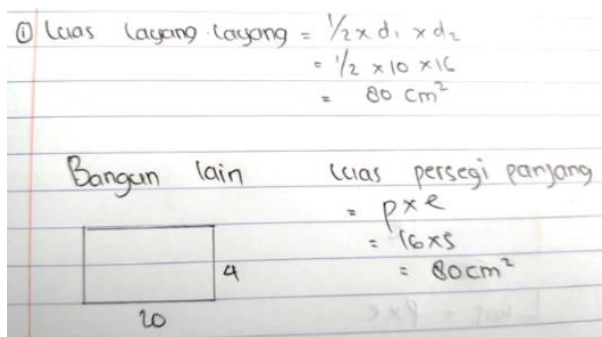

Figure 3 The results of AWS's answers on the aspect of fluency

In Figure 4, AWS shows that working on problem number 2 can determine the area of the composite plane in two different ways. AWS divides the composite plane into two planes in the first method, namely a square and a triangle. Then, she calculates the area of each and subtracts the area of the square from the area of the triangle to get the area of the composite plane. AWS divides the composite plane into two planes in the second method, namely rectangles and trapezoids. Therefore, AWS meets the flexibility indicator. This is complemented by excerpts from the interviews, as follows:

$\mathrm{R}$ : "In question number 2, how do you determine the area of the plane?"

AWS : "In the first method, I calculate the area of the square because the left and bottom sides are known to be $15 \mathrm{~cm}$ each. So, I assume the plane is a square. Then I subtract the area of a triangle with a base of $9 \mathrm{~cm}$ and a height of 11 $\mathrm{cm}$. Then, I calculate the second way by dividing the composite plane into rectangles and trapezoids, then adding up the two areas."

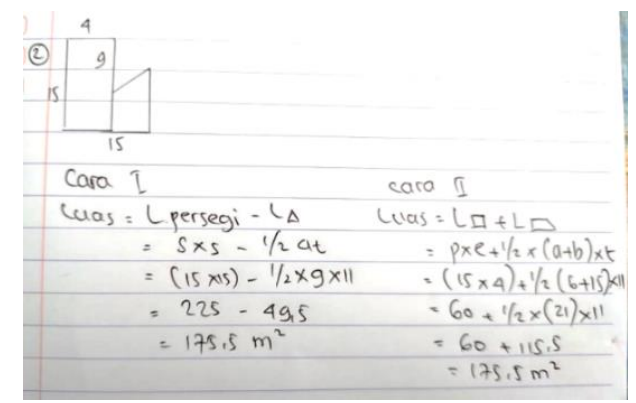

Figure 4 The results of AWS answers on the flexibility aspect

In Figure 5, working on problem number 3, AWS can determine another plane with the same area as a square. However, the only plane that AWS can create are rectangles with a length of $32 \mathrm{~cm}$ and a width of 8 $\mathrm{cm}$. Therefore, AWS does not meet the originality indicator.

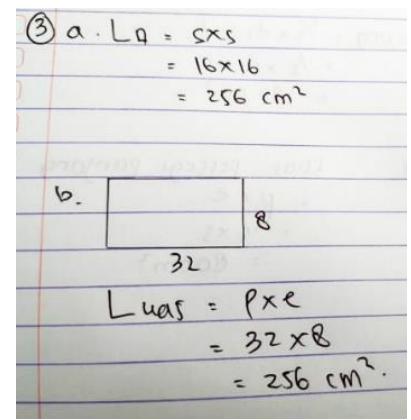

Figure 5 The results of AWS's answers on the aspect of originality

\subsection{Category 3: Creative}

Figure 6, Figure 7, and Figure 8 are answer sheets for RA subjects with creative categories. In Figure 6, working on problem number 1, RA can draw another plane whose area is the same as the area of the kite. The planes are rectangles, triangles, and parallelograms and their respective sizes. This is complemented by excerpts from the interviews, as follows:

$\mathrm{R}$ : "In question number 1, how do you determine a plane whose area is the same as the kite known in the question?"

RA : "First, I looked for the kite area and then found the area of $80 \mathrm{~cm}^{2}$. Then I made a rectangle. The area of a rectangle is the length times the width because the area is $80 \mathrm{~cm}^{2}$, so that I determine the length and width by finding two numbers multiplied that has result $80 \mathrm{~cm}^{2}$. So, the length is 10 $\mathrm{cm}$, and the width is $8 \mathrm{~cm}$. Building parallelograms and triangles, their methods are identical."

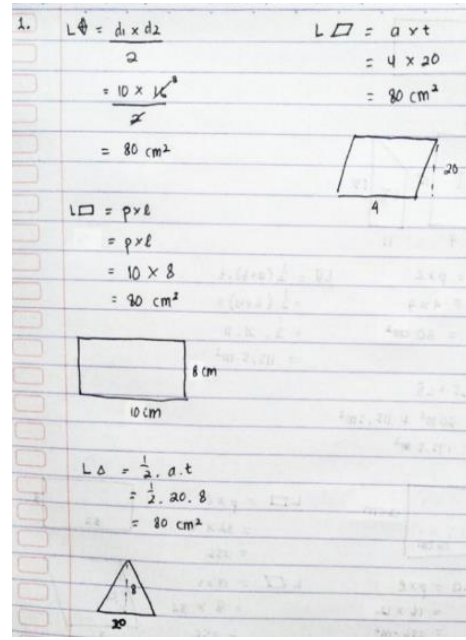

Figure 6 The results of RA's answer on the aspect of fluency 
In Figure 7, RA shows that working on problem number 2 can determine the area of the composite plane by dividing the composite plane into two different planes, namely rectangles and trapezoids. However, RA can only determine the area of the plane in one way.

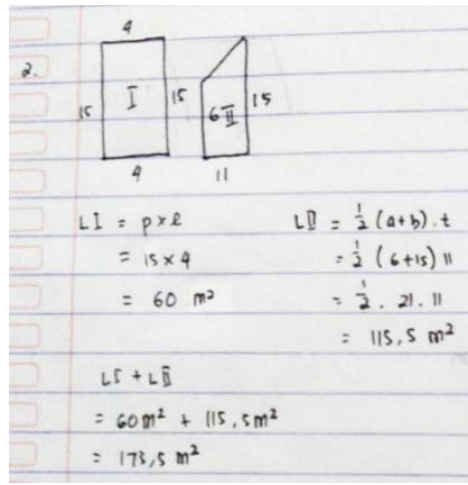

Figure 7 The results of RA's answer on the aspect of flexibility

In Figure 8, working on problem number 3, RA can determine another plane whose area is the same as a square. RA mentions three planes, namely rectangles, parallelograms, and one composite plane and their sizes. The composite plane drawn by RA is different from other students' answers, where this plane is a combination of rectangles and triangles. Therefore, RA meets the originality indicator. This is complemented by excerpts from the interviews, as follows:

$\mathrm{R} \quad$ : "What was asked in question number 3?"

RA : "Find another plane whose area is the same as the square in the problem."

R : "What do you build?"

RA : "I build rectangles, parallelograms, and composite plane from rectangles and triangles."

$\mathrm{R} \quad$ : "How do you determine the size of these planes?"

RA : "Building rectangles and parallelograms, the process is the same as in number 1 , which is to find the area of the square first. Then, determine the other two numbers, which are multiplied equally with the area of the square. For composite plane, I first determine the area of each plane. Here I determine the area of the rectangle is $192 \mathrm{~cm}^{2}$, and the triangle area is $64 \mathrm{~cm}^{2}$. Then, I just searched for each size of the triangle and rectangle. The method is the same as number 1 earlier. I look for two other numbers multiplied equally with the area of the square, which is $192 \mathrm{~cm}^{2}$, and the area of the triangle is $64 \mathrm{~cm}^{2}$."

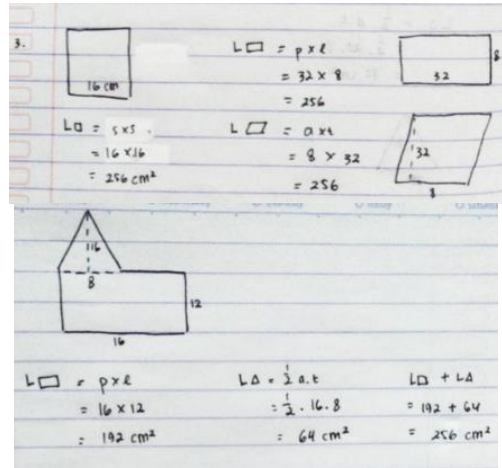

Figure 8 The results of RA's answer on the aspect of originality

\subsection{Category 4: Very Creative}

Figure 9, Figure 10, and Figure 11 are answer sheets for AA subjects with very creative categories. In Figure 9, working on problem number 1, AA can name three planes: triangles, rectangles, and parallelograms with the same area as a kite. AA can also draw these planes and determine the size of each plane. Therefore, AA meets the fluency indicator. This is complemented by excerpts from the interviews, as follows:

$\mathrm{R}$ : "In question number 1, how do you determine a plane whose area is the same as the kite known in the problem?"

AA : "First, I made a triangle. The area of the triangle is $1 / 2($ at) because the area is 80 $\mathrm{cm}^{2}$, so that I determined the base is $2 \mathrm{~cm}$ so it can be multiplied by $1 / 2$ and the height is $80 \mathrm{~cm}$ so that if it is calculated by the formula for the area of a triangle, the result is $80 \mathrm{~cm}^{2}$. Building parallelograms and rectangles, I look for two numbers multiplied equally with the result is 80 $\mathrm{cm}^{2}$."

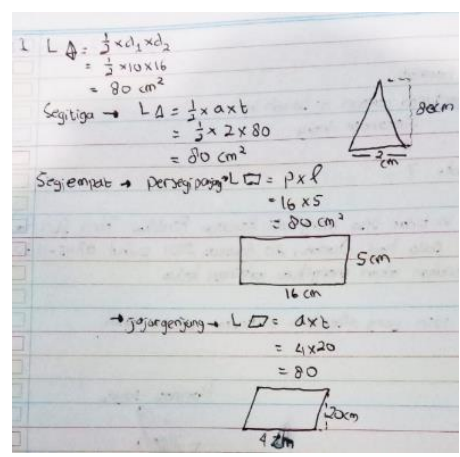

Figure 9 The results of AA's answer on the aspect of fluency 
In Figure 10 (question number 2), AA can determine the area of the composite plane in two different ways. In the first method, AA divides the composite plane into two planes: rectangles and trapezoids. In the second method, AA divides the composite plane into three planes, namely triangles and two rectangles with different sizes. Therefore, AA fulfills the flexibility aspect. This is complemented by excerpts from the interviews, as follows:

$\mathrm{R}$ : "In question number 2, how do you determine the area of the plane?"

AA : "I use two ways. First, I divided the plane into two planes: rectangle and trapezoid. Second, I divided the plane into three: rectangle, triangle, and rectangle. Then, I add up the area of each of the plane to find the area."

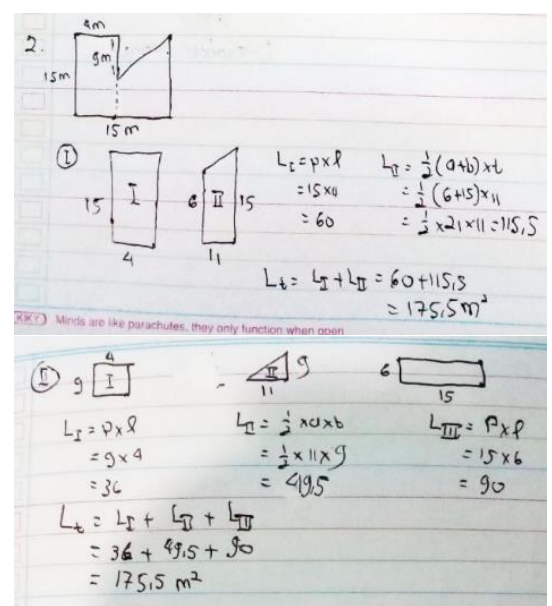

Figure 10 The results of AA's answer on the flexibility aspect

In Figure 11, working on problem number 3, AA can find another plane whose area is the same as a square. AA mentions four planes: kites, parallelograms, rectangles, and one composite plane and their sizes. The composite plane drawn by AA is different from other students' answers, where this plane is a combination of rectangles and trapezoids. Therefore, AA meets the originality indicator. This is complemented by excerpts from the interviews, as follows:

$\mathrm{R}$ : "What was asked in question number 3?" RA : "Create another plane that has the same area as a square."

R : "What do you build?"

RA : "Kites, parallelograms, rectangles, and composite plane."

$\mathrm{R} \quad$ : "The composite plane that you made are made of what combinations of planes?"

RA : "From rectangles and trapezoids."

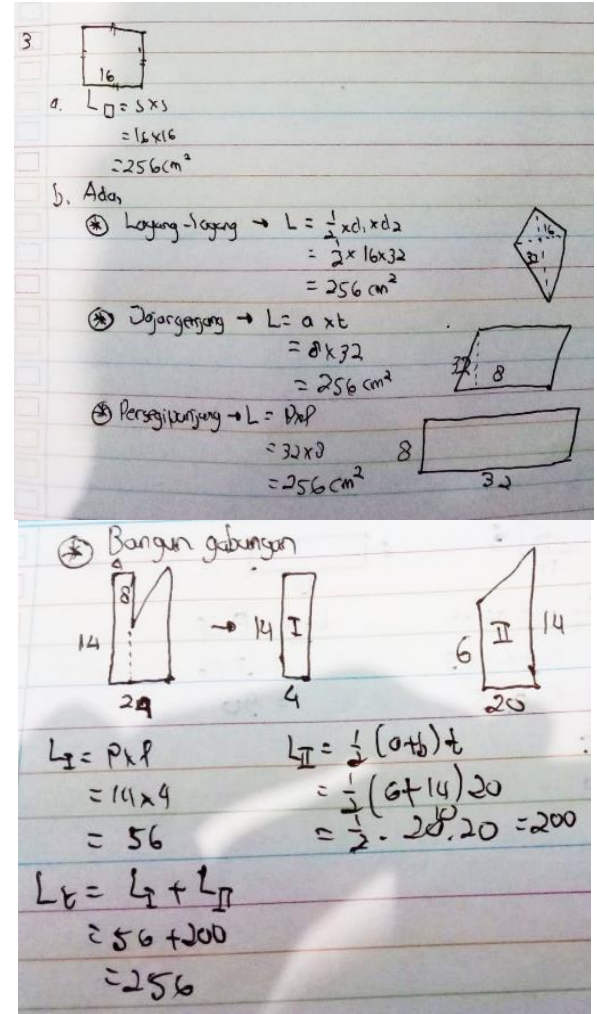

Figure 11 The results of AA's answer on the aspect of originality

\section{DISCUSSIONS}

Based on the results of the analysis that has been described, it can be said that the creative thinking abilities of students can be categorized into four levels or categories of creative thinking. In the very creative category, the subject of AA meets the three indicators of creative thinking, namely fluency, flexibility, and originality. The fluency indicator is indicated by the subject of AA being able to make three other planes whose area is the same as the kite area. The flexibility indicator is characterized by AA subjects being able to solve problems with two different methods. The originality indicator marked by the subject of AA can make different composite plane with other students. This is in line with research that has been done that individual who can solve problems by providing more than one solution, have variations in methods to overcome them. One of the solutions provided is different from the solutions of other individuals who meet the three indicators of creative thinking to be categorized into a very creative category [14]. In this category, individuals can meet the three indicators of creative thinking, namely fluency, flexibility, and originality [7]. 
In the creative category, the subject of RA meets two indicators of creative thinking, namely fluency and originality. The fluency indicator is indicated by the subject of RA being able to make three other planes whose area is the same as the kite area. The originality indicator is marked by the subject of RA making different composite plane with other students. The flexibility indicator is not met because the subject of RA only solves the problem with one method. Individuals in this category can meet two of the three indicators of creative thinking [15]. Individuals can give more than one correct answer and use different approaches or strategies [16]. This is under previous research that individuals who meet the indicators of fluency and flexibility or fluency and originality are categorized in the creative category [17].

In the quite creative category, AWS subjects only met one indicator of creative thinking, namely flexibility. The flexibility indicator is characterized by AWS subjects being able to solve problems with two different methods. The fluency indicator is not met because the AWS subject can only provide one plane in the form of a rectangle whose area is the same as the kite area. The originality indicator was not met because AWS subjects could not give different plane from other students. Individuals in this category tend to show indicators of flexibility, and some show indicators of originality [18]. Previous research stated that individuals in this category could provide different approaches to solve problems [16]. This is under the categorization that students who meet the flexibility or originality indicators can be categorized in the quite creative category [7].

In the less creative category, the RAA subject only met one indicator of creative thinking, namely fluency. The fluency indicator is indicated by the RAA subject's ability to provide a solution in the form of two planes with the same area as the kite. The flexibility indicator is not met because the RAA subject can only solve the problem with one method. The originality indicator was not met because the RAA subject could not give a different plane compared to other students. According to previous research, individuals who only meet the fluency indicator are less creative [19]. In this category, individuals tend to show one indicator of creative thinking in solving problems [18]. In addition, individuals in this category also tend to provide alternative answers that are not different from other individuals [16].

\section{CONCLUSION}

In conclusion, there are four categories of creative thinking in solving inquiry problems. First, students with less creative category have the characteristics of providing more than one alternative answer. Second, students with the category of quite creative have the characteristics of solving problems with more than one method. Third, students with creative category have the characteristics of providing more than one alternative answer and can give different answers from other students. Fourth, students with very creative category have the following characteristics: (1) can provide more than one alternative answer; (2) can solve problems with more than one method; and (3) can give different answers from other students.

The results of the study can be used as a theoretical guide for future research. Further research can develop an infused learning model to defragment students' creative level in solving inquiry problems.

\section{ACKNOWLEDGMENT}

The author would like to thank SMP Negeri 1 Nganjuk, mathematics teachers, and all students who have been willing to become research subjects.

\section{REFERENCES}

[1] S. Zubaidah, "Keterampilan Abad Ke-21: Keterampilan Yang Diajarkan Melalui Pembelajaran," Semin. Nas. Pendidik. dengan tema "Isu-isu Strateg. Pembelajaran MIPA Abad 21, no. Desember, pp. 1-17, 2016.

[2] C. Luna, "The Futures Of Learning 2: What Kind Of Learning For The 21st Century?," Educ. Res. Foresight, pp. 1-14, 2015.

[3] H. Türkmen and M. Sertkahya, "Creative Thinking Skills Analyzes of Vocational High School," J. Educ. Instr. Stud., vol. 5, no. 1, pp. 74-84, 2019.

[4] M. Nadjafikhah and N. Yaftian, "The Frontage of Creativity and Mathematical Creativity," Procedia-Soc. Behav. Sci., vol. 90, no. InCULT 2012, pp. 344-350, 2013, doi: 10.1016/j.sbspro.2013.07.101.

[5] M. Tendrita, S. Mahanal, and S. Zubaidah, "Pemberdayaan Keterampilan Berpikir Kreatif melalui Model Remap Think Pair Share," Proceeding Biol. Educ. Conf. (ISSN 2528-5742), vol. 13, no. 1, pp. 285-291, 2016.

[6] E. A. Silver, "Fostering creativity through instruction rich in mathematical problem solving 
and problem posing," Zentralblatt für Didakt. der Math., vol. 29, no. 3, pp. 75-80, 1997, doi: 10.1007/s11858-997-0003-x.

[7] T. Y. E. Siswono, "Level of student's creative thinking in classroom mathematics," Educ. Res. Rev., vol. 6, no. 7, pp. 548-553, 2011.

[8] H. Elgrably and R. Leikin, "Creativity as a function of problem-solving expertise: posing new problems through investigations," ZDM Math. Educ., vol. 53, no. 4, pp. 891-904, 2021, doi: 10.1007/s11858-021-01228-3.

[9] S. L. Laursen, M. L. Hassi, M. Kogan, and T. J. Weston, "Benefits for women and men of inquiry-based learning in college mathematics: A multi-institution study," J. Res. Math. Educ., vol. 45, no. 4, pp. 406-418, 2014, doi: 10.5951/jresematheduc.45.4.0406.

[10] K. Makar, A. Bakker, and D. Ben-Zvi, "Scaffolding norms of argumentation-based inquiry in a primary mathematics classroom," ZDM - Math. Educ., vol. 47, no. 7, pp. 11071120, 2015, doi: 10.1007/s11858-015-0732-1.

[11] S. Payton, "Fostering mathematical connections in introductory linear algebra through adapted inquiry," ZDM - Math. Educ., vol. 51, no. 7, pp. 1239-1252, 2019, doi: 10.1007/s11858-01901029-9.

[12] L. J. Moleong, Metodologi Penelitian Kualitatif. Bandung: PT Remaja Rosdakarya Offset, 2019.

[13] Budiyono, Pengantar Metodologi Penelitian Pendidikan. Surakarta: UNS Press, 2019.

[14] Sugiyono, Metode Penelitian Pendidikan Pendekatan Kuantitatif, Kualitatif, dan R\&D. Alfabeta, 2012.

[15] M. Huljannah, C. Sa'dijah, and A. Qohar, "Profil Berpikir Kreatif Matematis Mahasiswa Pendidikan Guru Sekolah Dasar," J. Pendidik. Teor. Penelitian, dan Pengemb., pp. 1428-1433, 2018, [Online]. Available: http://journal.um.ac.id/index.php/jptpp/article/vi ew/11730.

[16] E. S. Anwar, T. Wibowo, and I. Maryam, "Level Berpikir Kreatif Siswa Smp Dalam Menyelesaikan Masalah Matematika Dengan Pendekatan Realistic Mathematics Education," vol. 7, no. 2, pp. 59-67, 2020.

[17] P. Dwi Herdani and N. Ratu, "Analisis Tingkat Kemampuan Berpikir Kreatif Matematis Siswa SMP Dalam Menyelesaikan Open - Ended Problem Pada Materi Bangun Datar Segi Empat," JTAM | J. Teor. dan Apl. Mat., vol. 2, no. 1, p. 9, 2018, doi: 10.31764/jtam.v2i1.220.

[18] Y. N. Firdausi and M. Asikin, "Analisis Kemampuan Berpikir Kreatif Siswa Ditinjau dari Gaya Belajar pada Pembelajaran Model Eliciting Activities ( MEA )," FMIPA, Univ. Negeri Semarang, Semarang usiyusrotin@gmail.com, vol. 1, pp. 239-247, 2018.

[19] U. A. Febriyanti, H. Hobri, and S. Setiawani, "Tingkat Berpikir Kreatif Siswa Kelas VII dalam Menyelesaikan Soal Open-Ended Pada Sub Pokok Bahasan Persegi Panjang dan Persegi," J. Edukasi, vol. 3, no. 2, p. 5, 2016, doi: 10.19184/jukasi.v3i2.3521. 